\title{
Lipopolysaccharide treatment suppresses spontaneously developing ankylosing enthesopathy in B10.BR male mice: The potential role of interleukin-10
}

Jana Capkova ${ }^{1 \dagger}$, Tomas Hrncir ${ }^{2^{*}}$, Alena Kubatova ${ }^{1}$ and Helena Tlaskalova-Hogenova ${ }^{2}$

\begin{abstract}
Background: Ankylosing enthesopathy (ANKENT) is an animal model of human ankylosing spondylitis. ANKENT is an inflammatory disease affecting the ankle and tarsal joints of the hind limbs in susceptible mouse strains. In the disease, the participation of intestinal microbiota components was suggested. Therefore, we attempted to increase the incidence of ANKENT by systemic administration of lipopolysaccharide (LPS), which is a component of bacterial cellular walls and stimulates inflammatory processes.
\end{abstract}

Methods: ANKENT occurrence, serum cytokine profiles, spleen cellular composition and in vitro cytokine response to LPS were analysed in LPS-treated and control LPS-untreated B10.BR male mice.

Results: Contrary to expectations, LPS treatment decreased the incidence of ANKENT in LPS-treated group compared to control LPS-untreated group. Flow cytometry analysis of splenocytes showed an increased percentage of macrophages, dendritic cells and neutrophils and a decreased percentage of B cells, T cells and T helper cells in LPS-treated males following LPS administration. In addition, LPS-treated males had significantly elevated IL-6 and IL-10 serum levels. At 20-22 weeks after the final LPS application, splenocytes from LPS-treated mice were more susceptible to in vitro LPS stimulation than those of the controls and produced significantly higher levels of TNFa and IL-6.

Conclusions: Repeated systemic stimulation with microbial component lipopolysaccharide in early adulthood significantly reduced the incidence of ANKENT in B10.BR mice and this finding can support the "hygiene hypothesis". In LPS-treated mice, the innate immunity parameters and the level of anti-inflammatory IL-10 cytokine were significantly increased. Nevertheless, the immunological mechanism of the LPS protective effect remains unclear.

\section{Background}

Ankylosing spondylitis (AS) is a serious rheumatological disease resulting in patient disability. The disease affects mainly men and the first symptoms usually manifest themselves in early adulthood. A relevant genetic risk factor for AS is the HLA-B27 allele: $96 \%$ of AS patients carry the HLA-B27 gene [1,2]. To study the causes of AS, various biological models were created [3-6].

\footnotetext{
*Correspondence: tomas@gnotolab.com

${ }^{\dagger}$ Equal contributors

${ }^{2}$ Department of Immunology and Gnotobiology, Institute of Microbiology AS CR, v.vi.i, Doly 183, Novy Hradek 549 22, Czech Republic

Full list of author information is available at the end of the article
}

Our animal model for AS shows disease of the ankle and tarsal joints in the hind paws of mice. The disease affects joints and entheses, which are the areas of insertion of ligaments, tendons or joint capsules into bone. Analogously to human spondyloarthropathies (SpA) $[7,8]$, enthesitis is a specific marker of the affected joints and the disease was classified as ankylosing enthesopathy (ANKENT) [9]. The disease occurs spontaneously in some inbred mouse strains $[10,11]$ and almost exclusively in males [12]. Its incidence is significantly increased in HLA-B27 mice [11], confirming an implication of the B27 allele in ANKENT development.

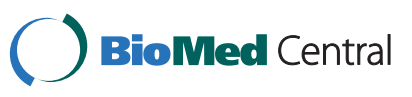


The disadvantage of the ANKENT model is the relative low frequency of the disease - about 10\% B10.BR male mice under conventional (CV) and about 5\% mice under specific pathogen free (SPF) conditions naturally develop ANKENT [11].

In previous studies, we found that germ-free mice remain ANKENT free [13] and their colonization with a mixture containing a low number of common intestinal bacteria (Bacteroides sp., Enterococcus sp., Staphylococcus sp., Veillonella sp.) alone results in ANKENT development [14]. Because mucosal barrier impairment and the consequent increased penetration of commensal microbiota components were suggested to play a role in the disease development [15], we attempted to induce ANKENT and increase its frequency through the systemic administration of lipopolysaccharide (LPS). LPS, a component of bacterial cellular walls, is an efficient stimulator of the immune inflammatory response [16] and its intraperitoneal application increases intestinal permeability [17]. A further aim of our work was to study the immunological profile of ANKENT-susceptible B10.BR mice during LPS administration and at the end of the observation period and to compare it to that of LPS-untreated control mice.

\section{Methods}

Mice

ANKENT- susceptible inbred B10.BR (C57BL/10 genetic background, $\mathrm{H}-2^{\mathrm{k}}$ haplotype) male mice born to females at the age of $2 \frac{1}{2}-3$ months were used in the experiments. The litters were split before sexual maturity and males from each litter were divided into two groups: LPS-treated and control LPS-untreated (PBS-treated) group. In the experiment there were 73 LPS-treated males and 88 LPS-untreated control males. In the course of LPS administration, after the second and the fourth LPS dose, and at the end of the experiment, i.e. 2022 weeks after the fourth LPS dose, always 9 LPStreated and 9 control males were sacrificed and sera and spleens collected (Figure 1). All mice were housed under the same conventional conditions, fed the same diet and caged 4-6 males together.

All experiments were approved by the Institutional Animal Care Committees of the Institute of Biotechnology and the Institute of Microbiology and were in accordance with the EC Directive 86/609 EEC for animal experiments.

\section{ANKENT screening and evaluation}

ANKENT is a progressive stiffening of the ankle and tarsal joints in the hind paws of mice. Joint stiffness was evaluated by gentle stretching once a week and a score between 0 (normal mobility) and 3 (completely immobile) was assigned. Scores of 2 and above were regarded as clearly positive for ANKENT. Joints of some ANKENT positive animals were also checked by radiography. The mice were observed until they reached the age of 10 months.

\section{LPS and its administration}

LPS was isolated from E. coli O83 and purified by phenol-water extraction [18]. Twenty mg of LPS was dissolved in $20 \mathrm{ml}$ of sterile PBS and the solution was administered immediately or aliquoted and stored at $20{ }^{\circ} \mathrm{C}$ until used. Mice were intraperitoneally (i.p.) injected with LPS (100 $\mu \mathrm{g}$ LPS/0.1 ml PBS per mouse) four times at two-week intervals. At the beginning of LPS treatment the males were $3-3 \frac{1}{2}$ months old. Control LPS-untreated mice were injected i.p. with $0.1 \mathrm{ml}$ PBS according to the same schedule.

\section{Antibodies}

The following monoclonal antibodies with matching isotype controls were used: PE-conjugated anti-mouse CD19 for detection of B cells; FITC-conjugated antimouse CD3e, FITC-conjugated anti-mouse CD4, PEconjugated anti-mouse CD8a and PE-conjugated antimouse Foxp3 for detection of T cells and their subpopulations; PE-conjugated anti-mouse CD49b for detection of NK cells; PE-conjugated anti-mouse CD11b, FITCconjugated anti-mouse $\mathrm{CD} 11 \mathrm{c}$, and $\mathrm{PE}-\mathrm{Cy} 5$ conjugated anti-mouse Ly-6 G for detection of leukocyte populations. All monoclonal antibodies were purchased from eBioscience, USA.

\section{Flow cytometry}

Phenotypic analysis of cells isolated from the spleen was performed using flow cytometry (FACS). Cells were resuspended in ice-cold FACS buffer (1\% bovine serum albumin and $0.1 \%$ sodium azide in PBS) to a concentration of $2 \times 10^{7}$ cells $/ \mathrm{ml}$ and pre-incubated with $1 \mu \mathrm{g}$ of anti-mouse CD16/CD32 per $10^{6}$ cells for $5 \mathrm{~min}$ on ice prior to staining. Antibodies were diluted to predetermined optimal concentrations in $50 \mu \mathrm{l}$ of FACS buffer and dispensed into wells of a 96-well microtiter plate. Fifty $\mu \mathrm{l}$ of the cell suspension was added to each well and incubated for $20 \mathrm{~min}$ at $4{ }^{\circ} \mathrm{C}$ in darkness. Then, the cells were washed twice and resuspended in $100 \mu \mathrm{l}$ of FACS buffer. Intracellular staining of mouse Foxp3 was performed using PE anti-mouse Foxp3 Staining Set according to the manufacturer's protocol. Sample data were acquired using FACSCalibur flow cytometer (Becton Dickinson, USA) and analysed with FlowJo software (Tree Star, USA).

\section{Serum samples}

Blood samples were collected the third day after the second and the fourth LPS dose and at the end of 


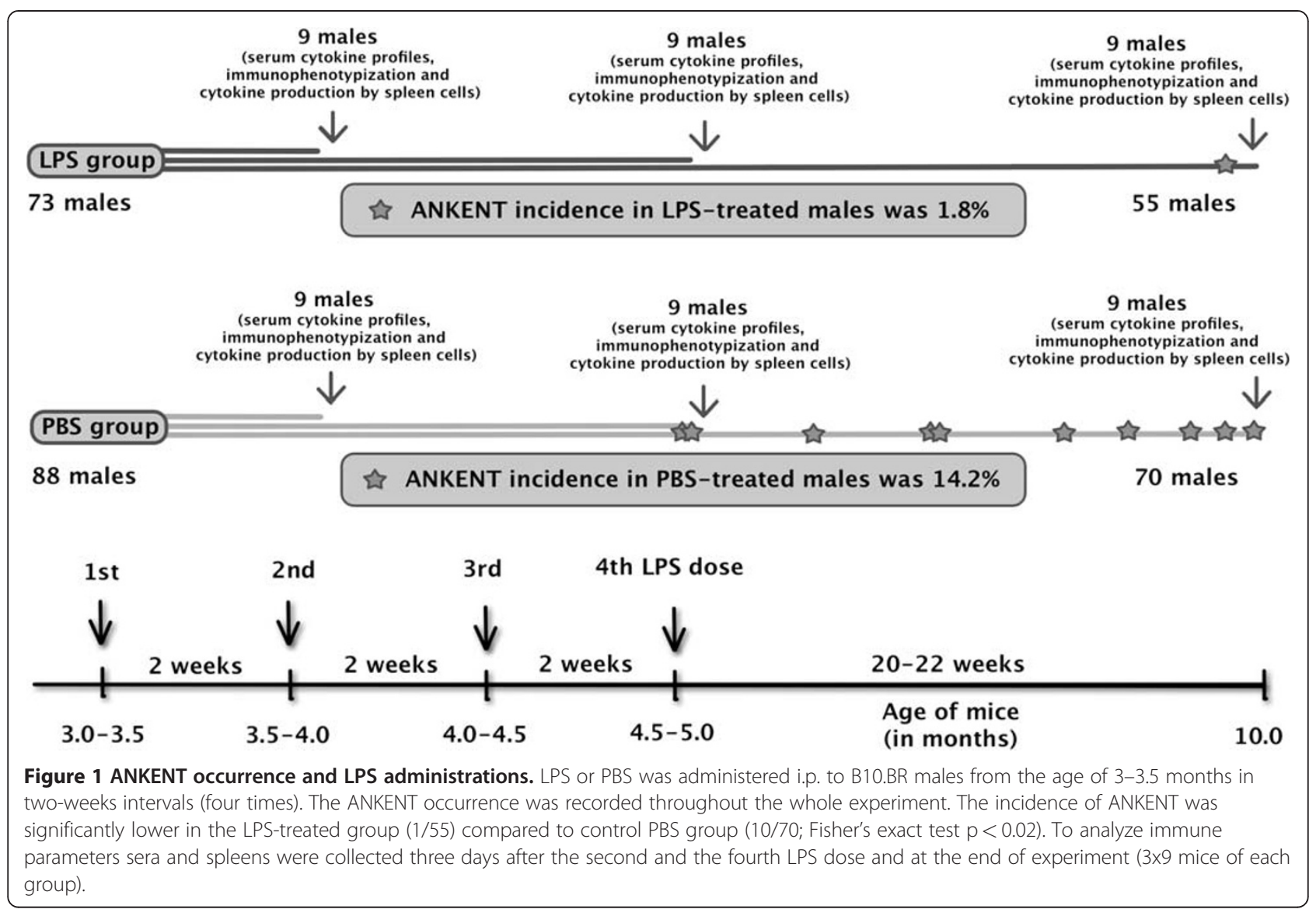

experiment (Figure 1). Not treated blood was let stand for $2 \mathrm{~h}$ at room temperature, centrifuged and sera were collected and stored at $-20{ }^{\circ} \mathrm{C}$ until cytokine analysis.

\section{In vitro cytokine stimulation}

Spleen cells were cultured at $2 \times 10^{6}$ cells $/ \mathrm{ml}$ in a 96well flat-bottom culture plate in complete RPMI-1640 medium. The cells were stimulated with $10 \mu \mathrm{g} / \mathrm{ml}$ LPS and incubated in $5 \% \mathrm{CO}_{2}$ at $37{ }^{\circ} \mathrm{C}$ for $48 \mathrm{~h}$.

\section{Multiplex cytokine determination}

Cytokine levels in sera and supernatants were detected using fluorescent beads coated with analyte-specific capture antibodies (BioSource, USA) according to the manufacturer's protocols. The beads were analyzed using the Bio-Plex System (Bio-Rad Laboratories, Hercules, USA).

\section{Statistical analysis}

Statistical differences in ANKENT occurrence between LPS-treated and control groups were evaluated by Fisher's exact test (two-tailed). P values less than 0.05 were considered statistically significant.

Data concerning the proportional representation of cell populations and cytokine levels are expressed as mean \pm standard deviation (SD). Statistical differences between LPS-treated and control groups were examined using the Student's $t$ test. A p-value of $<0.05$ was considered statistically significant. Statistical significance was analyzed using Prism 5.0 statistical software (GraphPad Software, San Diego, CA).

\section{Results}

\section{ANKENT occurrence}

ANKENT occurs particularly in inbred mouse strains with the C57BL genetic background. The disease begins with mild swelling and redness in the ankle area and in a short period of time (2-4 weeks) culminates in irreversible stiffening of the ankle and tarsal joints (Figure 2). Proliferative inflammation of the joints and adjacent tissues causes ossification of the joint cartilage [10] which is well seen on a radiograph (Figure 3).

Among LPS-treated males we found only one ANKENT positive male, i.e. $1.8 \%$ (1/55) incidence. On the other hand, ANKENT occurrence in the control LPSuntreated males was relatively high and joint disease developed in $14.2 \%(10 / 70)$ cases (Figure 1). Statistical evaluation by Fisher's exact test demonstrated a significant difference in ANKENT incidence between LPStreated and control males $(\mathrm{p}<0.02)$. 


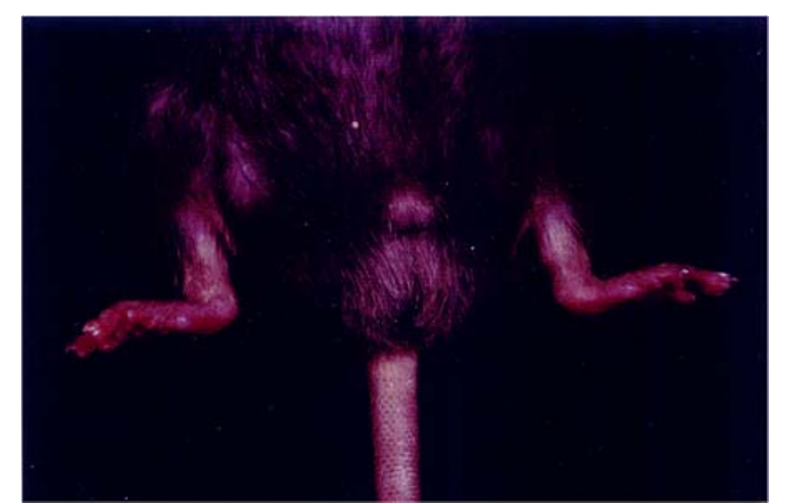

Figure 2 ANKENT in both paws. A 7-month-old ANKENT-positive male from the control LPS-untreated group with both paws affected.

\section{Leukocyte subpopulations in the spleen}

FACS analysis of spleen cells showed that LPS stimulation affected the proportion of macrophages $(\mathrm{CD} 11 \mathrm{~b}+)$, dendritic cells $(\mathrm{CD} 11 \mathrm{c}+)$ and neutrophils $(\mathrm{Ly}-6 \mathrm{G}+)$ in the spleen (Figure 4). After the second LPS dose, LPStreated males had a significantly higher percentage of CD11b+, CD11c + and Ly-6G+ leukocytes $\quad(p<0.01)$ compared to control LPS-untreated males (Figure 4A). The increased percentage of CD11b+and Ly-6G+cells $(\mathrm{p}<0.01)$ also persisted after the fourth LPS dose (Figure 4B). However, at the end of the experiment both LPS-treated and control males had almost identical proportions of leukocyte subpopulations (Figure 4C) and no statistical differences were found between the LPStreated and the control group.

\section{Lymphocyte subpopulations in the spleen}

Significant differences in lymphocyte subpopulations in the spleen were observed between LPS-treated and control LPS-untreated males through the course of LPS

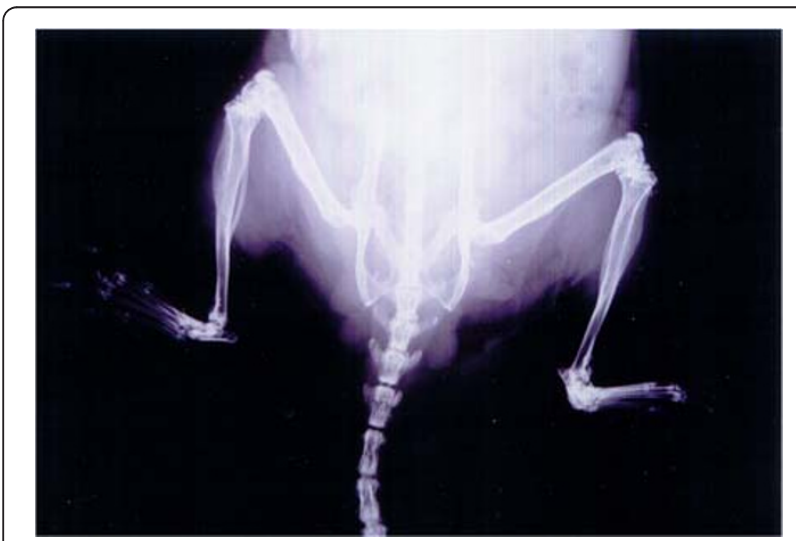

Figure 3 A radiograph of ANKENT-positive male. A control LPS-untreated male with the right paw affected. The left paw is normal.

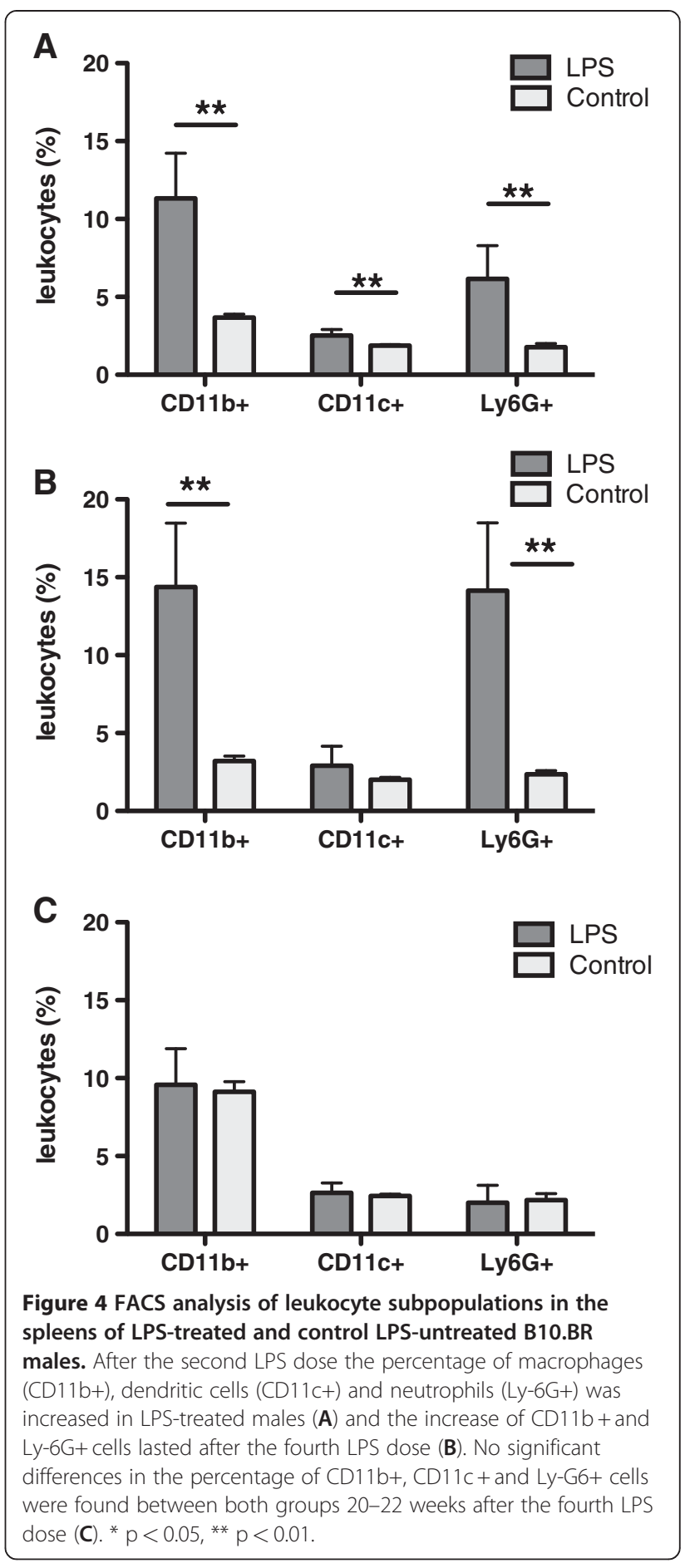

administration (Figure 5). FACS analysis of splenocytes demonstrated a decreased percentage of CD19+ B cells $(\mathrm{p}<0.05), \mathrm{CD} 3+\mathrm{T}$ cells $(\mathrm{p}<0.01)$ and CD4+ T helper cells $(\mathrm{p}<0.01)$ after the second LPS dose (Figure $5 \mathrm{~A})$. The decrease in percentage of CD19+ B cells $(p<0.01)$ persisted and even deepened after the fourth LPS dose (Figure 5B). The percentage of CD8+, CD4+Foxp3+ and $\mathrm{CD} 3+\mathrm{CD} 49 \mathrm{~b}+\mathrm{T}$ cells remained unaffected by the LPS 


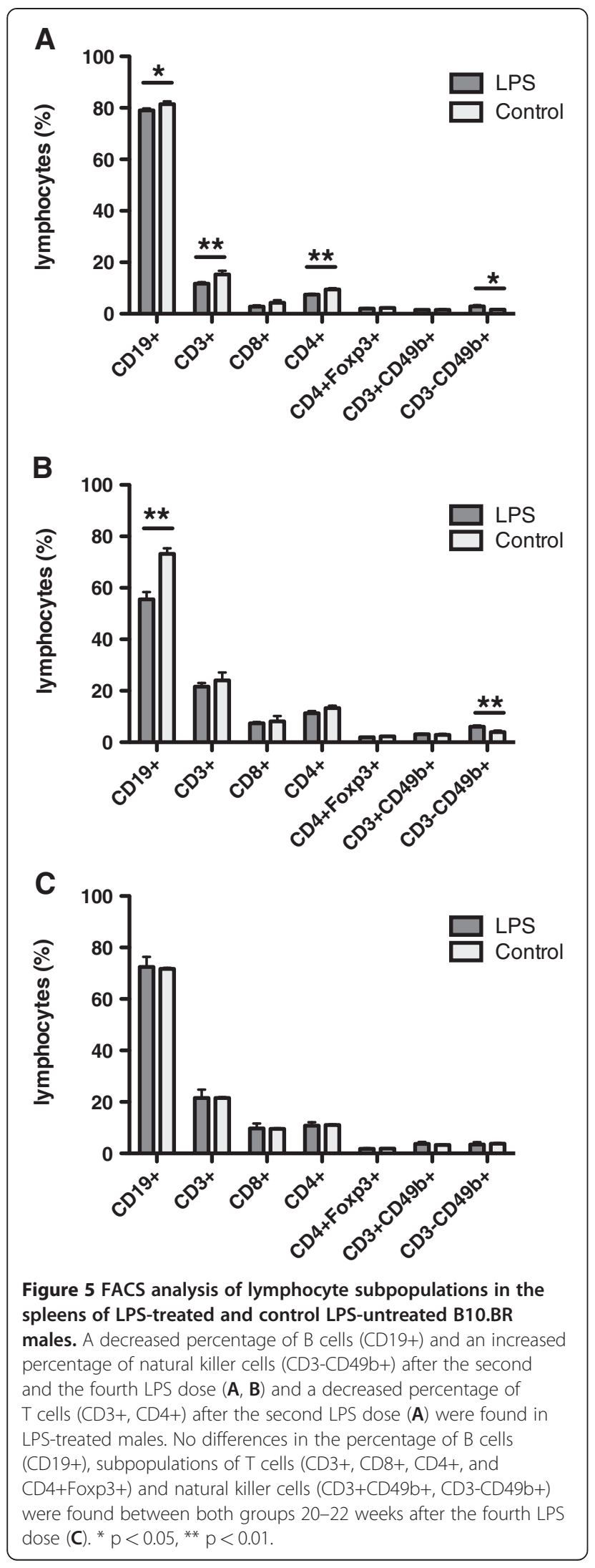

treatment (Figure 5A, B). The proportion of CD3$\mathrm{CD} 49 \mathrm{~b}+$ natural killer cells was increased in LPS-treated males compared to control males $(\mathrm{p}<0.05$ resp. $\mathrm{p}<0.01$ ) (Figure 5A, B). At the end of the observation period the expression of B cells (CD19+), T cells (CD3+), cytotoxic $\mathrm{T}$ cells $(\mathrm{CD} 8+)$, helper $\mathrm{T}$ cells $(\mathrm{CD} 4+)$, and regulatory $\mathrm{T}$ cells $(\mathrm{CD} 4+$ Foxp3+) as well as natural killers (CD3$\mathrm{CD} 49 \mathrm{~b}+)$ and natural killer $\mathrm{T}$ cells $(\mathrm{CD} 3+\mathrm{CD} 49 \mathrm{~b}+)$ was comparable and nearly identical in both groups (Figure 5C).

\section{Cytokine levels in blood sera}

The following cytokines were measured: TNF $\alpha$, IL-6, IFN $\gamma$, TGF $\beta$, and IL-10. After the second and the fourth LPS dose there were significantly elevated levels of IL-6 $(\mathrm{p}<0.01)$ and IL-10 $(\mathrm{p}<0.01)$ (Figure 6A, B). At the end of the experiment the levels of TNF $\alpha$, IL-6, and IFN $\gamma$ cytokines were not significantly different between the LPS-treated and the control group and the levels of TGF $\beta$ and IL-10 cytokines were bellow the detection limit of the method (Figure 6C). However, IL-6 and TNFa were elevated in both LPS-treated and PBStreated control groups (Figure 6C).

\section{In vitro cytokine response of spleen cells}

Spleen cells from LPS-treated and control males were stimulated in vitro with LPS and the levels of TNF $\alpha$, IL-6, IFN $\gamma$, TGF $\beta$ and IL-10 in cell supernatants were evaluated (Figure 7). After the fourth LPS dose the IL-6 level was significantly higher in LPS-treated males $(p<0.05)$ than in the controls (Figure 7B). Twenty-two weeks after the final LPS dose the splenocytes isolated from LPS-treated males were more susceptible to LPS stimulation and produced significantly higher levels of pro-inflammatory cytokines TNF $\alpha(\mathrm{p}<0.01)$ and IL-6 $(\mathrm{p}<0.05)$ than splenocytes from LPS-untreated control males (Figure 7C).

\section{Discussion}

Bacterial lipopolysaccharide (endotoxin) triggers acute inflammation, associated with activation of the innate immune system and production of multiple proinflammatory mediators $[19,20]$. In this study, we attempted to utilize the proinflammatory capability of LPS to enhance the incidence of the naturally occurring inflammatory joint disease ANKENT in mice.

ANKENT develops almost exclusively in males and this hallmark of the disease is associated with hormonal and behavioural factors - similarly as in naturally occurring arthritis in DBA/1 male mice [21]. The males caged together have a significantly higher risk of ANKENT development than males caged alone [22]. During the whole experiment both LPS-treated and LPS-untreated males were caged under the same conditions and we 


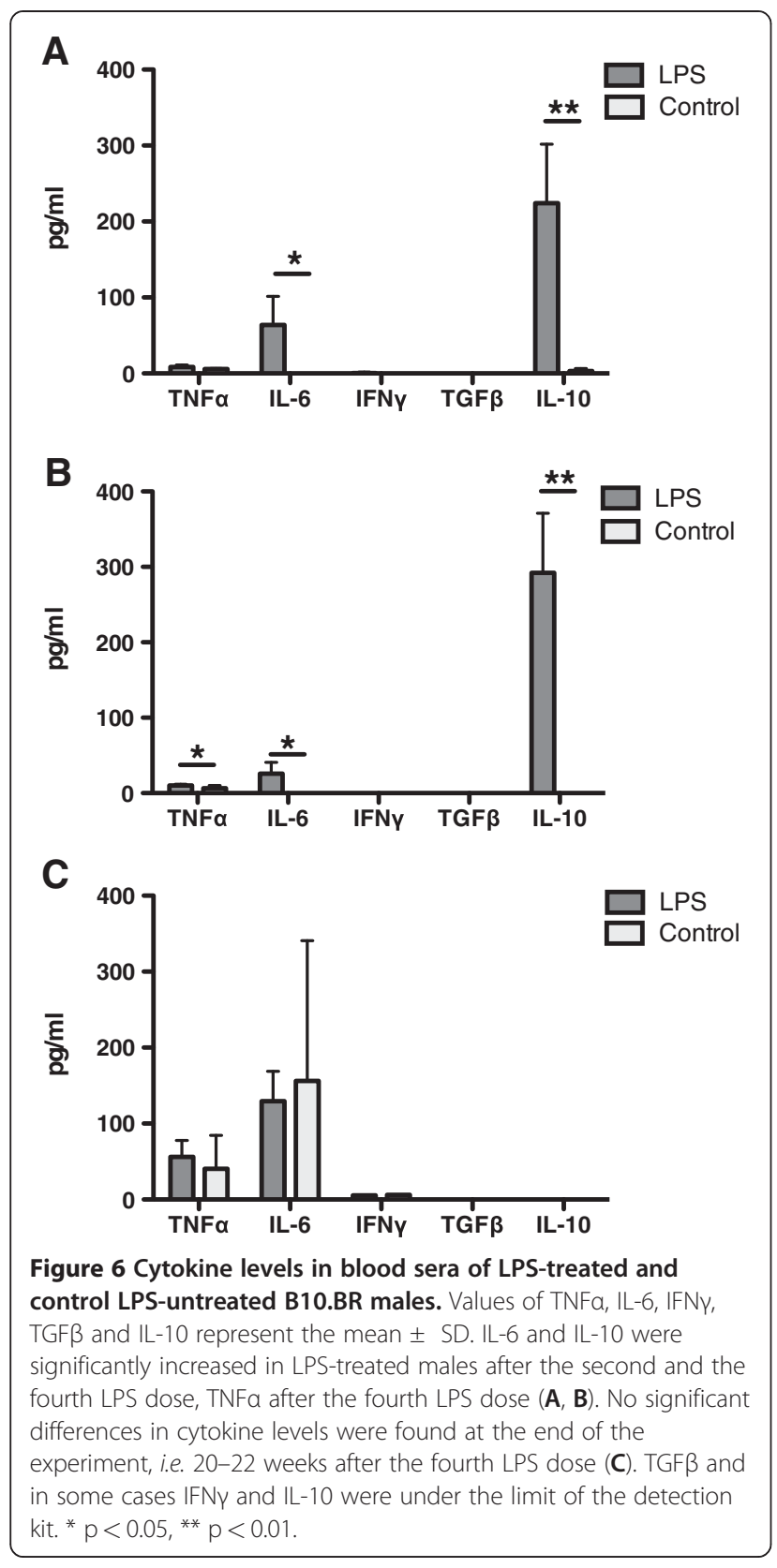

have not observed any significant difference in behaviour between the groups.

Previously, we showed that germ-free mice do not suffer from the joint disease [13]. However, after their colonization with a mixture containing common intestinal bacteria, some mice developed ANKENT [14]. The close connection between the gut and SpA was repeatedly demonstrated in laboratory animals [23-27] and was also confirmed in humans [28-33]. Because LPS is an agent which when administered intraperitoneally enhances intestinal permeability, and leads to translocation of commensal microbiota from the gut [17], we expected a higher frequency of the disease in LPS-

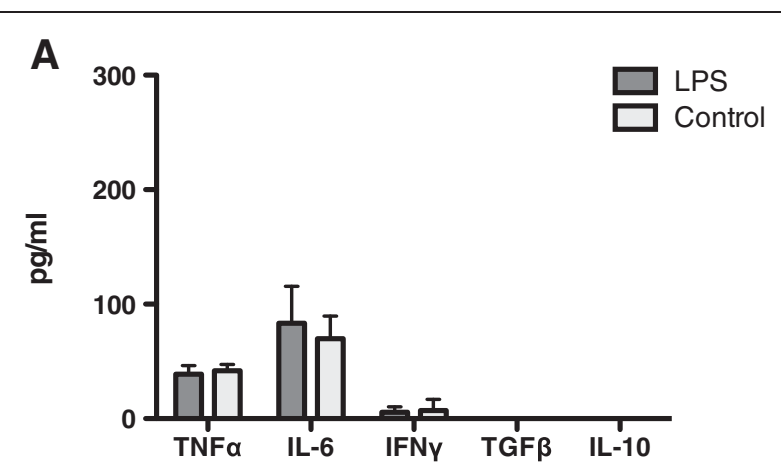

B
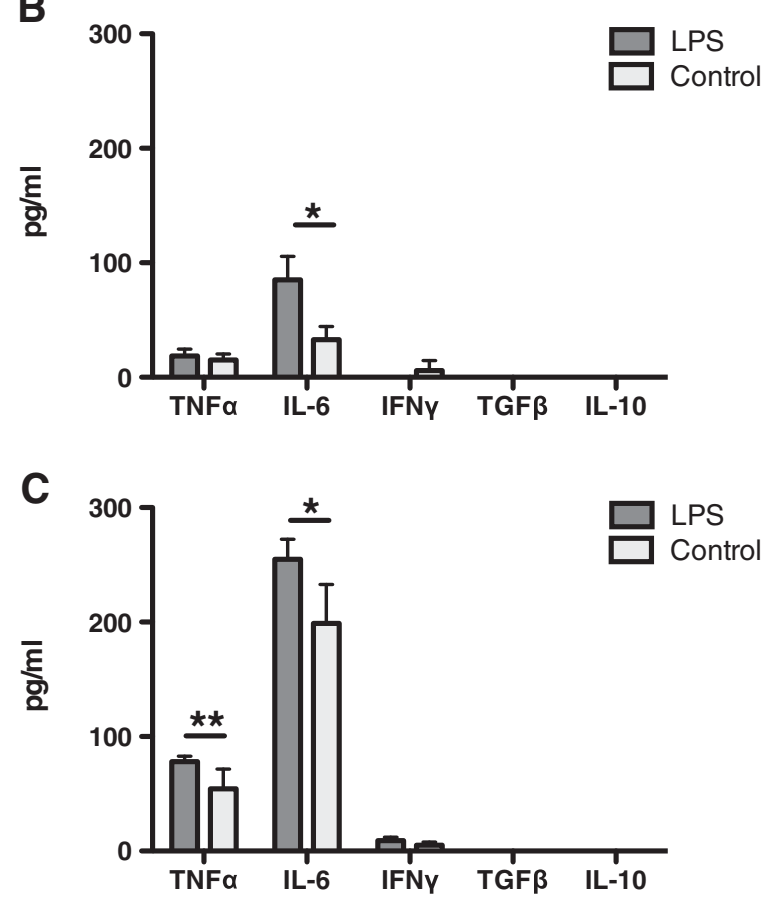

Figure 7 In vitro cytokine response of splenocytes from LPS-treated and control LPS-untreated B10.BR males to LPS stimulation. TNFa, IL-6, IFNY, TGF $\beta$ and IL-10 in cell supernatants were determined. No significant differences were found between LPS-treated males and the control group after the second LPS dose (A). After the fourth LPS dose the IL-6 level was significantly increased in LPS-treated males (B). At the end of the experiment splenocytes from LPS-treated males responded to LPS stimulation by significantly higher production of TNFa and IL-6 cytokines (C). * $p<0.05$, ** $p<0.01$.

treated males. Surprisingly, LPS administration to ANKENT-susceptible B10.BR male mice in their early adulthood acted protectively: the incidence of ANKENT in LPS-treated males was significantly reduced compared to control LPS-untreated group. This unexpected result could be explained by an overactivation of innate immunity cells leading to an upregulation of negative regulatory pathways [34].

The second aim of our work was to study the immune response. The cellular infiltrate in joints and elevated IL- 
6 levels in the sera were demonstrated in ANKENT positive animals at the time when ANKENT became manifest $[9,11]$. These signs disappeared after the period of acute inflammation. In this study we did not test mice in the acute stages of the disease, but we were interested in the immune response that precedes ANKENT onset. We compared populations of immune cells and cytokine levels in LPS-treated group, where ANKENT occurrence was suppressed, with the control LPS-untreated group, where ANKENT was manifest.

Throughout the course of LPS administration, significantly higher percentages of macrophages $(\mathrm{CD} 11 \mathrm{~b}+)$, dendritic cells $(\mathrm{CD} 11 \mathrm{c}+)$, neutrophils (Ly6G+) and also natural killer cells (CD3-CD49b+) were found in LPStreated males than in LPS-untreated ones. This LPSinduced expansion of innate immune cells in spleen was transient and was not present at the end of experiment when the frequencies of these populations were similar in both groups.

Just the opposite effect of LPS treatment was observed in lymphocyte subpopulations. During LPS administration the percentage of $\mathrm{B}$ cells, $\mathrm{T}$ cells and $\mathrm{T}$ helper cells in the spleen was significantly decreased in LPS-treated males and the decrease in frequency of $\mathrm{B}$ cells lasted throughout LPS treatment. At the end of the experiment, no differences were found between LPS-treated and LPS-untreated males. This suggests that cells of the adaptive immune system did not directly participate in the immune response to LPS treatment, and the suppression of adaptive immunity in LPS-treated males might be involved in the reduction of ANKENT incidence.

Specific cells of innate and adaptive immunity are associated with the production of cytokines. In LPStreated males we found significantly increased serum levels of IL-6 and IL-10 during LPS administration, whereas the percentage of CD4+ T cells, which is an important source of these cytokines, was decreased. However, macrophages also produce IL-6 and monocytes, whose frequency was strongly elevated in LPS-treated males, are the main cellular source of IL-10.

The finding of significantly elevated IL-10 levels in sera of LPS treated males was discrepant with the in vitro response of LPS stimulated splenocytes, which did not secrete detectable IL-10. This contradiction between serum and in vitro spleen cell response to LPS stimulation could be explained by the fact that the major source of circulating IL-10 after LPS stimulation is liver [35].

No significant serum differences were found between LPS-treated and LPS-untreated males in IL- 6 and IL-10 and in all other tested cytokines at the end of the experiment. However, IL-6 and TNFa were elevated in both groups. The elevation of these pro-inflammatory cytokines at the end of experiment could be explained by the presence of ANKENT-positive animals. We could only speculate that LPS treatment suppressed and delayed the onset of ANKENT and that cytokine data both from serum and from in vitro stimulation show the subclinical signs of disease. Nevertheless, at the end of the experiment we have detected only a single affected mouse in LPS-treated group. To evaluate the data in more detail we would need to match single cytokine data with individual mice. However, both LPS-treated as well as LPS-untreated control males were evaluated as a group.

We do not know the exact mechanism of LPS effect in ANKENT development, but the high level of antiinflammatory cytokine IL-10 could contribute to homeostasis in LPS-treated males. IL-10, which is a potent anti-inflammatory agent, might suppress the onset of ANKENT by its effect on the secretion of proinflammatory cytokines including TNF $\alpha$ and IL-6. A regulation of IL-10 is connected with a function of proinflammatory TNF $\alpha$. In mice, TNF $\alpha$ up-regulates LPSinduced IL-10 synthesis and neutralization of TNFa with anti TNF $\alpha$ antibody results in a significant reduction of LPS-inducible IL-10 production [35].

To better understand the immune mechanisms underlying the development of ANKENT, in vitro LPS stimulation of splenocytes was performed. In the course of LPS administration we observed an elevated level of IL-6 in supernatants of splenocytes from LPS-treated males. This result was consistent with the elevated IL-6 levels in blood sera from the LPS group. At the end of the experiment we found not only further increase in IL-6 levels but also increase in TNF $\alpha$ levels in both groups. The levels of both TNF $\alpha$ and IL- 6 were significantly higher in LPS-treated group compared to control group. TNF $\alpha$ is directly produced by macrophages in response to LPS stimulation [36] and is also a typical marker for AS in man [37]. The anti-TNF monoclonal antibodies that act by neutralizing TNF have proved highly effective in AS therapy, but also in the treatment of other spondyloarthropathies $[38,39]$.

\section{Conclusions}

According to our results we conclude:

1. Repeated systemic stimulation with the microbial component LPS caused an activation of the innate immune system followed by suppression of both arms of the immune system in the LPS-treated males. These changes correlated with the reduction of the ANKENT incidence.

2. Considerable increase in the anti-inflammatory IL10 level in the LPS-treated males can be a potential mechanism that decreased the ANKENT incidence. 
3. Our findings suggest that LPS stimulated development, expansion and function of the immune system so that LPS-treated males were less susceptible to ANKENT development than LPSuntreated controls.

\section{Abbreviations \\ ANKENT: Ankylosing enthesopathy; AS: Ankylosing spondylitis; \\ SpA: Spondyloarthropathies; LPS: Lipopolysaccharide; TNFa: Tumor necrosis

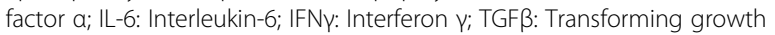 factor $\beta$; IL-10: Interleukin-10; PBS: Phosphate-buffered saline. \\ Competing interests \\ The authors declare that they have no competing interests.}

\section{Acknowledgements}

We would like to thank Dr. S. Takacova for language help and advice on the preparation of this manuscript. This work was supported by Institutional Research Supports (AVOZ 50520701 and RVO 61388971), by grants from Czech Science Foundation (310/09/P182 and 304/11/1252) and by a grant from Ministry of Education, Youth and Sports of the Czech Republic (7E09091).

\section{Author details}

'Laboratory of Diagnostics for Reproductive Medicine, Institute of Biotechnology AS CR, v.v.i., Videnska 1083, Prague 142 20, Czech Republic.

${ }^{2}$ Department of Immunology and Gnotobiology, Institute of Microbiology AS CR, v.vi.i, Doly 183, Novy Hradek 549 22, Czech Republic.

\section{Authors' contributions}

HTH and JC proposed conception and experimental design. JC, TH and AK carried out LPS treatment, ANKENT screening, immunoassays and acquisition of data. HTH, TH and JC analyzed and interpreted obtained data. JC, HTH and TH drafted the manuscript and revised it critically. All authors read and approved the final manuscript.

Received: 28 August 2011 Accepted: 15 June 2012 Published: 21 June 2012

\section{References}

1. Brewerton DA, Hart FD, Nicholls A, Caffrey M, James DC, Sturrock RD: Ankylosing spondylitis and HL-A 27. Lancet 1973, 1:904-907.

2. Schlosstein L, Terasaki PI, Bluestone R, Pearson CM: High association of an HL-A antigen, W27, with ankylosing spondylitis. N Engl J Med 1973, 288:704-706.

3. Breban M, Hacquard-Bouder C, Falgarone G: Animal models of HLA-B27associated diseases. Curr Mol Med 2004, 4:31-40.

4. Khare SD, Luthra HS, David CS: Spontaneous inflammatory arthritis in HLA-B27 transgenic mice lacking beta 2-microglobulin: a model of human spondyloarthropathies. J Exp Med 1995, 182:1153-1158.

5. Nordling C, Karlsson-Parra A, Jansson L, Holmdahl R, Klareskog L: Characterization of a spontaneously occurring arthritis in male DBA/1 mice. Arthritis Rheum 1992, 35:717-722.

6. Taurog JD: Animal models of spondyloarthritis. Adv Exp Med Biol 2009, 649:245-254.

7. D'Agostino MA, Said-Nahal R, Hacquard-Bouder C, Brasseur JL, Dougados M, Breban M: Assessment of peripheral enthesitis in the spondylarthropathies by ultrasonography combined with power Doppler: a cross-sectional study. Arthritis Rheum 2003, 48:523-533.

8. Granfors K, Marker-Hermann E, de Keyser F, Khan MA, Veys EM, Yu DT: The cutting edge of spondylarthropathy research in the millennium. Arthritis Rheum 2002, 46:606-613.

9. Eulderink F, Ivanyi P, Weinreich S: Histopathology of murine ankylosing enthesopathy. Pathol Res Pract 1998, 194:797-803.

10. Capkova J, Ivanyi P: $\mathrm{H}-2$ influence on ankylosing enthesopathy of the ankle (ANKENT). Folia Biol (Praha) 1992, 38:258-262.

11. Weinreich S, Eulderink F, Capkova J, Pla M, Gaede K, Heesemann J, van Alphen L, Zurcher C, Hoebe-Hewryk B, Kievits F, et al: HLA-B27 as a relative risk factor in ankylosing enthesopathy in transgenic mice. Hum Immunol 1995, 42:103-115.
12. Capkova J, Ivanyi P, Rehakova Z: Sexual dimorphism, but not testosterone itself, is responsible for ankylosing enthesitis of the ankle in B10.BR (H-2k) male mice. Ann Rheum Dis 2006, 65:130-132.

13. Rehakova Z, Capkova J, Stepankova R, Sinkora J, Louzecka A, Ivanyi P, Weinreich S: Germ-free mice do not develop ankylosing enthesopathy, a spontaneous joint disease. Hum Immunol 2000, 61:555-558.

14. Sinkorova Z, Capkova J, Niederlova J, Stepankova R, Sinkora J: Commensal intestinal bacterial strains trigger ankylosing enthesopathy of the ankle in inbred B10.BR (H-2(k)) male mice. Hum Immunol 2008, 69:845-850.

15. Tlaskalova-Hogenova H, Stepankova R, Hudcovic T, Tuckova L, Cukrowska B, Lodinova-Zadnikova R, Kozakova H, Rossmann P, Bartova J, Sokol D, et al: Commensal bacteria (normal microflora), mucosal immunity and chronic inflammatory and autoimmune diseases. Immunol Lett 2004, 93:97-108.

16. Munford RS: Sensing gram-negative bacterial lipopolysaccharides: a human disease determinant? Infect Immun 2008, 76:454-465.

17. Mishima $S, X u D, L u Q$, Deitch EA: The relationships among nitric oxide production, bacterial translocation, and intestinal injury after endotoxin challenge in vivo. J Trauma 1998, 44:175-182.

18. Westphal O, Luderitz O, Bister F: Uber die Extraktion von Bakterien mit Phenol/Wasser. Z Naturforsch 1952, 7:148-155.

19. Aird WC: The role of the endothelium in severe sepsis and multiple organ dysfunction syndrome. Blood 2003, 101:3765-3777.

20. Guha M, Mackman N: LPS induction of gene expression in human monocytes. Cell Signal 2001, 13:85-94.

21. Holmdahl R, Jansson L, Andersson M, Jonsson R: Genetic, hormonal and behavioural influence on spontaneously developing arthritis in normal mice. Clin Exp Immunol 1992, 88:467-472.

22. Weinreich S, Capkova J, Hoebe-Hewryk B, Boog C, Ivanyi P: Grouped caging predisposes male mice to ankylosing enthesopathy. Ann Rheum Dis 1996, 55:645-647.

23. Hacquard-Bouder C, Ittah M, Breban M: Animal models of HLA-B27associated diseases: new outcomes. Joint Bone Spine 2006, 73:132-138.

24. Milia AF, Ibba-Manneschi L, Manetti M, Benelli G, Messerini L, MatucciCerinic M: HLA-B27 transgenic rat: an animal model mimicking gut and joint involvement in human spondyloarthritides. Ann N Y Acad Sci 2009, 1173:570-574

25. Onderdonk AB, Richardson JA, Hammer RE, Taurog JD: Correlation of cecal microflora of HLA-B27 transgenic rats with inflammatory bowel disease. Infect Immun 1998, 66:6022-6023.

26. Rath HC, Herfarth HH, Ikeda JS, Grenther WB, Hamm TE Jr, Balish E, Taurog JD, Hammer RE, Wilson KH, Sartor RB: Normal luminal bacteria, especially Bacteroides species, mediate chronic colitis, gastritis, and arthritis in HLA-B27/human beta2 microglobulin transgenic rats. J Clin Invest 1996, 98:945-953.

27. Taurog JD, Richardson JA, Croft JT, Simmons WA, Zhou M, Fernandez-Sueiro $J$, Balish E, Hammer RE: The germfree state prevents development of gut and joint inflammatory disease in HLA-B27 transgenic rats. J Exp Med $1994,180: 2359-2364$.

28. Ciccia F, Bombardieri M, Principato A, Giardina A, Tripodo C, Porcasi R, Peralta S, Franco V, Giardina E, Craxi A, et al: Overexpression of interleukin23 , but not interleukin-17, as an immunologic signature of subclinical intestinal inflammation in ankylosing spondylitis. Arthritis Rheum 2009, 60:955-965.

29. de Vlam K, Mielants H, Cuvelier C, De Keyser F, Veys EM, De Vos M: Spondyloarthropathy is underestimated in inflammatory bowel disease: prevalence and HLA association. J Rheumatol 2000, 27:2860-2865.

30. Faustini F, Zoli A, Ferraccioli GF: Immunologic and genetic links between spondylarthropathies and inflammatory bowel diseases. Eur Rev Med Pharmacol Sci 2009, 13(Suppl 1):1-9.

31. Jacques P, Mielants H, Coppieters K, De Vos M, Elewaut D: The intimate relationship between gut and joint in spondyloarthropathies. Curr Opin Rheumatol 2007, 19:353-357.

32. Palm O, Moum B, Ongre A, Gran JT: Prevalence of ankylosing spondylitis and other spondyloarthropathies among patients with inflammatory bowel disease: a population study (the IBSEN study). J Rheumatol 2002, 29:511-515.

33. Rodriguez-Reyna TS, Martinez-Reyes C, Yamamoto-Furusho JK: Rheumatic manifestations of inflammatory bowel disease. World J Gastroenterol 2009, 15:5517-5524

34. Biswas A, Wilmanski J, Forsman $\mathrm{H}$, Hrncir T, Hao L, Tlaskalova-Hogenova $\mathrm{H}$, Kobayashi KS: Negative regulation of Toll-like receptor signaling plays an 
essential role in homeostasis of the intestine. Eur J Immunol 2011, 41:182-194

35. Barsig J, Kusters S, Vogt K, Volk HD, Tiegs G, Wendel A: Lipopolysaccharideinduced interleukin-10 in mice: role of endogenous tumor necrosis factor-alpha. Eur J Immunol 1995, 25:2888-2893.

36. Zhang WJ, Wei H, Hagen T, Frei B: Alpha-lipoic acid attenuates LPSinduced inflammatory responses by activating the phosphoinositide 3kinase/Akt signaling pathway. Proc Natl Acad Sci U S A 2007, 104:4077-4082.

37. Old L: Tumor necrosis factor (TNF). Science 1985, 230:630-632.

38. Oldfield V, Plosker GL: Golimumab: in the treatment of rheumatoid arthritis, psoriatic arthritis, and ankylosing spondylitis. BioDrugs 2009, 23:125-135.

39. Sieper J: Developments in the scientific and clinical understanding of the spondyloarthritides. Arthritis Res Ther 2009, 11:208.

doi:10.1186/1471-2474-13-110

Cite this article as: Capkova et al.: Lipopolysaccharide treatment suppresses spontaneously developing ankylosing enthesopathy in B10. BR male mice: The potential role of interleukin-10. BMC Musculoskeletal Disorders 2012 13:110.

\section{Submit your next manuscript to BioMed Central and take full advantage of:}

- Convenient online submission

- Thorough peer review

- No space constraints or color figure charges

- Immediate publication on acceptance

- Inclusion in PubMed, CAS, Scopus and Google Scholar

- Research which is freely available for redistribution 